الخلاصة:

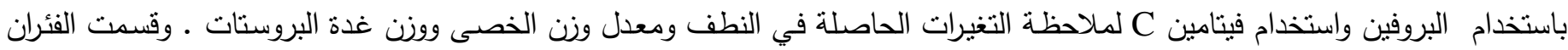

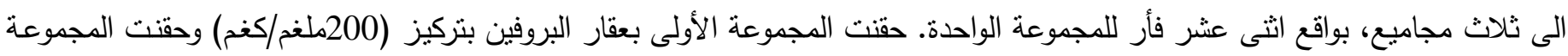
الثانية بعقار البروفين وفيتامين C بتركيز (200 ملغم/كغم) لكل منهما أما المجموعة الثالثة من الفئران فكانت مجموعة السيطرة والتي حقنت

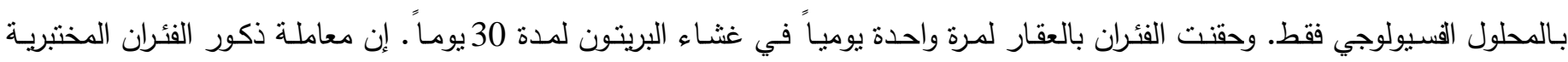

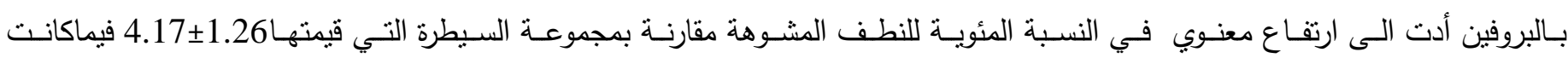

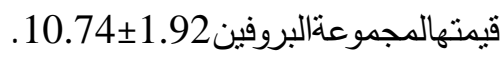

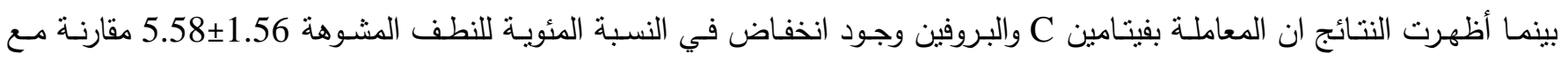

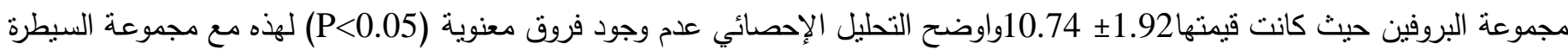

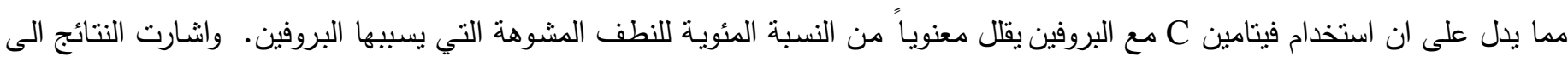

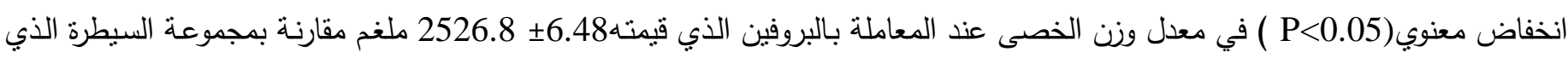

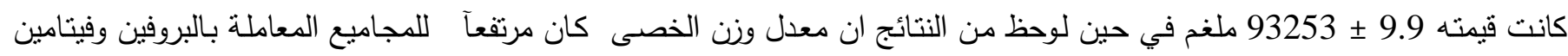

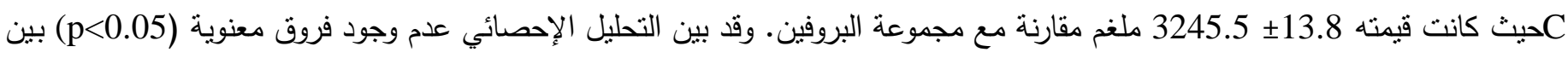

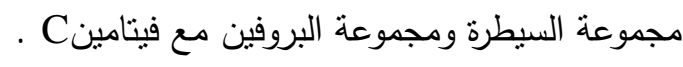

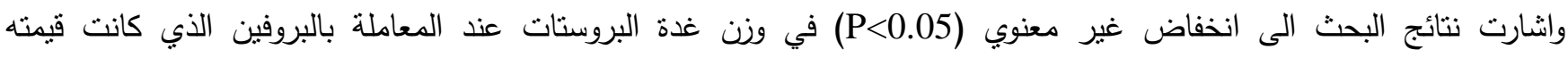

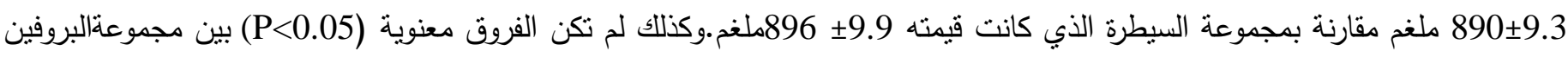
وفيتامين C حيث كانت قيمته 900_9.0 ملغم عند مقارنتها مع مجموعة السيطرة ومجموعة البروفين.

لكعالجة الالتهابات. وان البروفين من العوامل المضادة للالتهابات

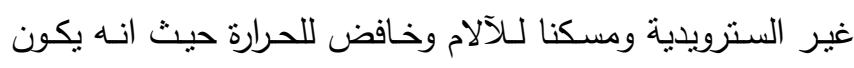
على شكل بلورات عديمة اللون وغير ذائبة في الماء نسبياً لكنه يعد البروفين من المواد الكيميائية المصنعة أو الأدوية التي

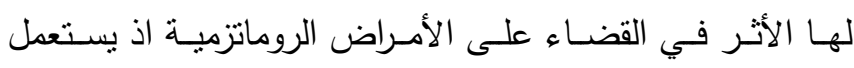


نظـراً لفعاليتهــا وقلــة الآثـار الجانبيـة الخطيـرة مقارنــة بالأدويـة

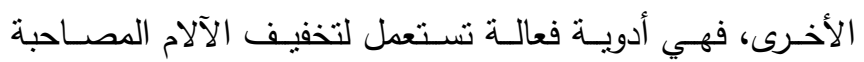
(Cole et al., 1988; Wollf, لإمراض العظام والمفاصل

يعرف فيتامين c أيضـاً باسم Ascorbic acid والذي يعد

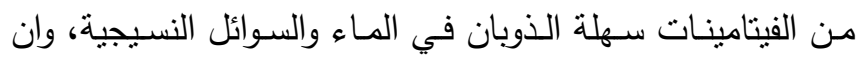

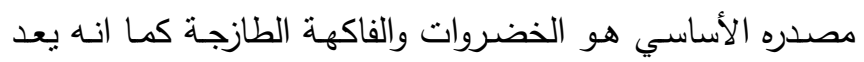

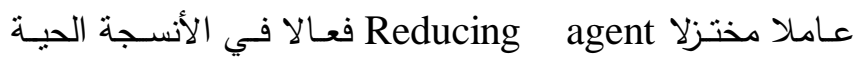
(Cole et. al.,1988). وفي ضوء ذللك فانه يؤدي دوراً مهما في العديد من العمليات الحياتيـة داخل الجسم حيث انه مطلوب في

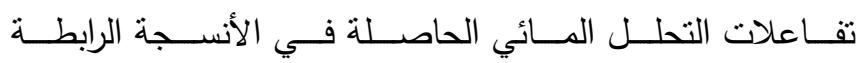
Connective tissues الامينية Amino acids ويساهم أيضاً في التئام الجروح وتايض الدهون (Smirnoff, 2001; Lee et. al., 2000). يعد (لاند مـرض الإسـقربوط Scurvy هـو الهـرض الأساسـي والمعـروف

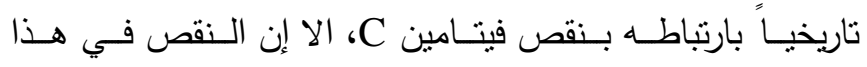

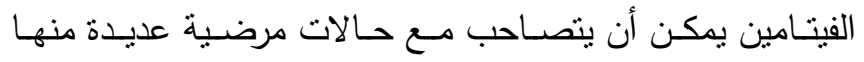
ضعف الأنسجة الرابطة والألياف مابين العظام وهشاشـة الأسنان

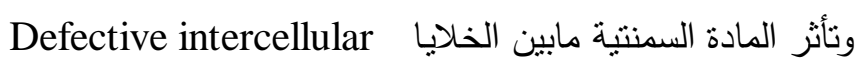
cement . كذلك تصبح الأوعية الدمويـة الثـعرية رقيقة وعرضـه للتمزق والنزف تحت الجلد Capillary hemorrhage والذي قد يتصاحب مع فقر دم ثانوي(Lee et. al.,2000). وقد أثشارت الدراسـات الى إن زيـادة استهلاك فيتـامين C يسـاعد في اختزال مخاطر مرض الثريان التاجي (Coronary heart disease) وذلك من خـلال عدد من الآليات المضـادة للأكسدة وبالاعتمـاد على قابليتـهـ فـي خفض مسـتوى الكولسـترول في مصـل الـدم

.(Moller \& Loft, 2002)

ان فحص نشوهات النطف هو فحص يستخدم للكثف عن السمية الوراثية التي تحدثها العوامل الفيزيائية والكيميائية في المادة

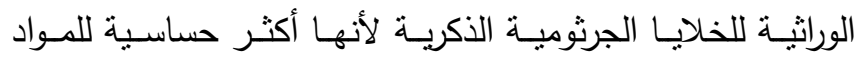
المطفرة أثناء تكوين النطف التي تكون عملية متواصلة ومستمرة لذا تظهر تغيرات في الثـكل الظـاهري لرأس النطفة الناتجـة من من
يذوب في المذيبات العضوية مثل الكحول والايثز وله رائحة مميزة

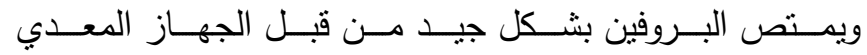
المعوي(Verbeek, 1990). يسـتخدم البـروفين فـي عـلاج رومـاتزم مفاصـلـ السـلامية القاصية وأيضـاً استعمل لإزالة التشنجات للمرضسى الذين يعانون

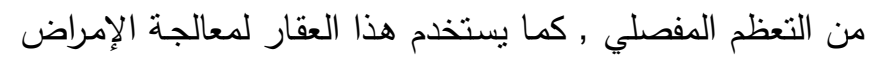

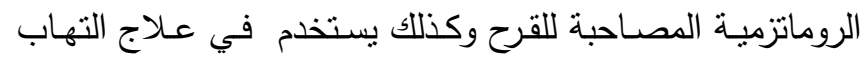
المفاصل الحاد، وعلاج الآم عسر الطمث وعلاج الآلام الحاصلة بعد العمليات الجراحية وكذلك لعلاج الإصابات الفيروسية البسيطة

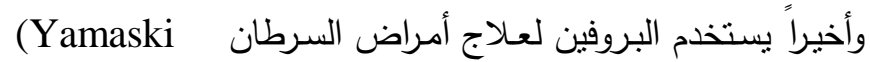
.and Ames, 1977)

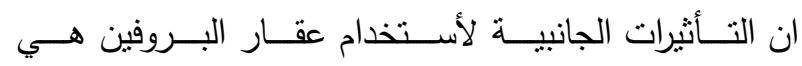

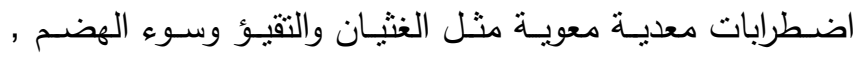

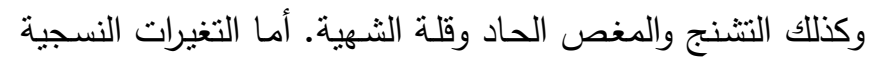
أو الداخليـة الناتجـة مـن العـلاج بـالبروفين فهي التحطم الأنبوبي

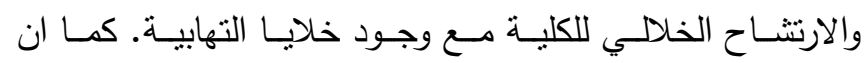
البروفين يمكن أن يحدث النخر الحليمي في اللب الكلوي وتطور حالة التبول الدموي. وعند التحليل البولي بعد التجريع بـالبروفين

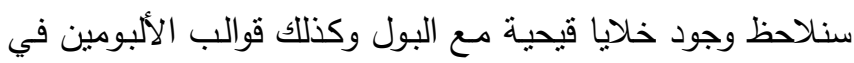
الخلية المبطنة للنبيبات الكلوية (Verbeek, 1990).

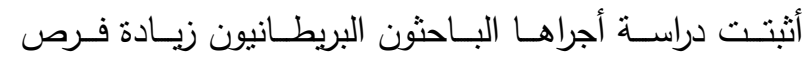

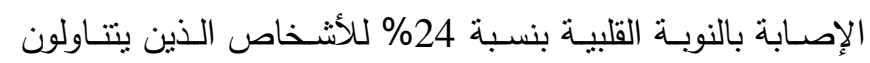

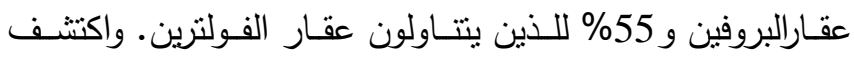

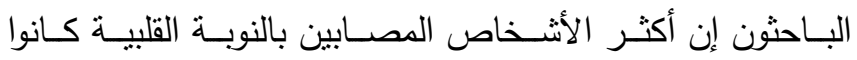
يتتـاولون أدويـة مضـادة للالتهـاب لفترة 3 أثــــر قبـل أصـابتهم

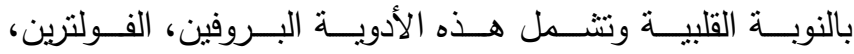

النايروكسين، الفايوكس و السلبريكس(West et. al., 1994). كما وضـح الباحثن الأوربيون إن مثل هذه الأدويـة المسكنة

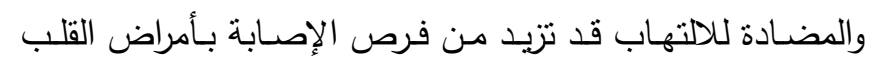

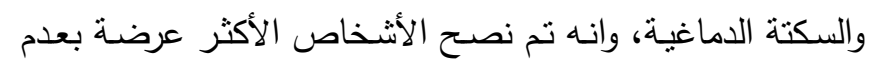
تتاول هذه الأنواع من الأدوية(Wiley, 1989). الأدوية المضادة ولته

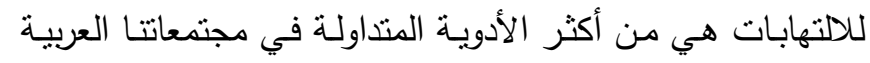


1 - أثنى عشرفأرآ حقنت بالبروفين بتركيز 200ملغ/كغم0.1 مل مرة في اليوم وعلى مدى 30 يوم.

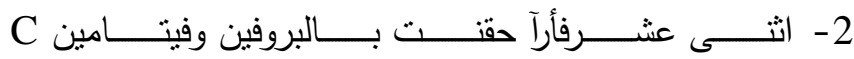
بنزكيز 200م/كغم 0.1 مل لكل منهما مرة في اليوم وعلى

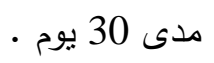

3 - رافقت هذه المجاميع أنثى عشرفارآ سيطرة حقنت بالمحلول

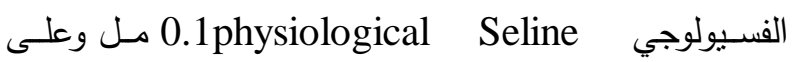

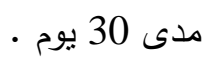

إن العقارين المستخدمان في البحث هما البروفين وفيتامين من صنع شركة عراقية (سامراء - العراق) واستخدم هذين العقارين

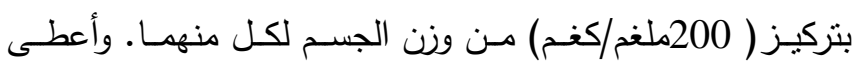
البروفين وفيتامين C بمعدل جرعة واحدة في اليوم حيث تعطى الجرعة في الساعة العاشرة صباحا ويتم الحقن عن طريق غثاء البريتون وتم حقن 0.1 مل من محلول البروفين لاثثي عشرفارآ

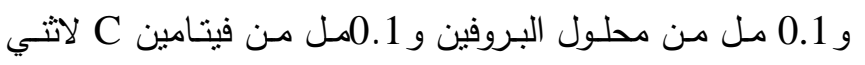
عشرفأرآ.

Solutions : المحاليل:

1 - محلول دارئ الفوسفات الملحي Phosphate Buffered

Saline :

أذيبت الدكونات أدناه في (500مل) من الماء المقطر ثم أكمل الحجم الى (1000مل).

1

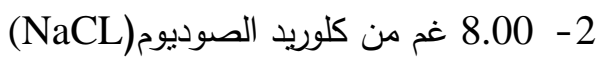

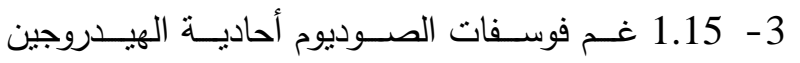

(Na2Hpo4)

4 - 0.20 غــم فوســات البوتاســيوم ثنائيــة الهيـــروجين

(KH2po4)

وثبت الرقم الهيدروجيني (PH) عند (7.2) وعقم بالموصدة وحفظ

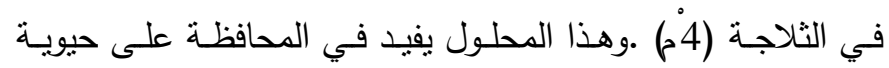
الخلايا كما كانت في جسم الكائن الحي. 2 - صبغة الايوسين : Eosin Stain
حدوث خلل في تمايز النطف والذي يقع تحت سيطرة وراثيـة (Topham, 1980) وقد اختبرت العديد من المواد الكيميائية المطفرة والمسرطنة والمعروفة على أحداث تغيرات في الخلايا

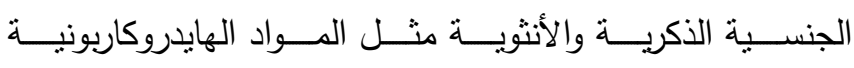
كالبزانثراسين، حيث وجد انه يحدث نسبة عالية من التشوهات في ولاني

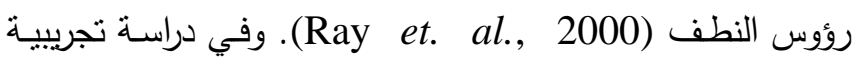
وجدت إن فيتامين C ظهر كمضـاد لأكسدة دنا DNA النطف عندما تكون مستويات التخذية الحاوية على فيتامين C كفؤة لحفظ السائل المنوي. بينما تقل نسبة حركة النطف في المدخنين ويمكن

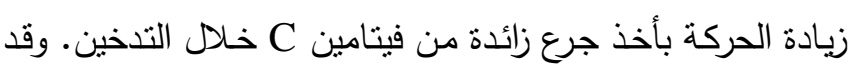

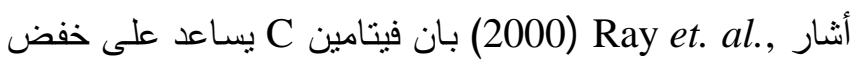

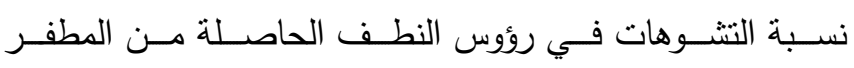
البنزانثراسين.ويهدف هذا|البحث الى دعرفة تأثير البروفين والبروفين وفيتامين C Cي اوزان الخصى والبروستات والنطف في ذكور الفئران البيض - البين : الموادوطرق العق • 1

اجري البحث على ذكور الفئران البيضـاء Bate mice

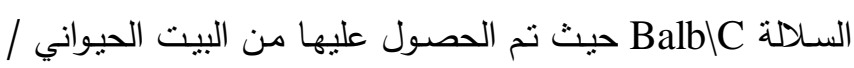

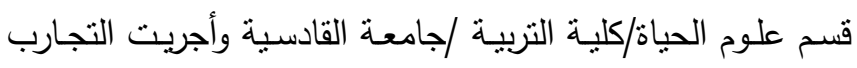

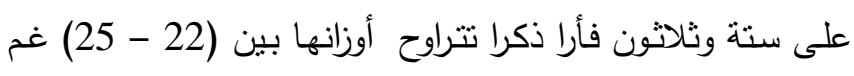

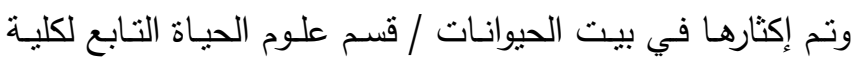

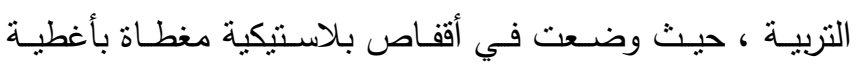

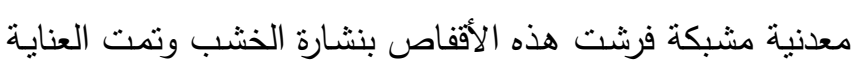

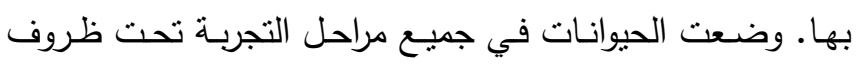

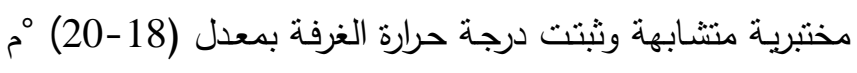

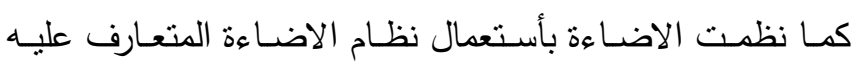

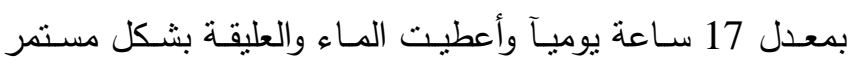

خلال مدة التجربة. قسمت ذكور الفئران الى ثلاثة مجاميع : 
وعلى طول البطن حتى عظم القص ، ثم تم فصل الخصية ،

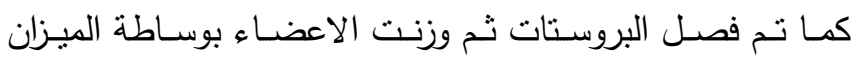
الالكتروني الحساس (sartorius ) .

1 - النسبة المئوية للنطف المشوهة

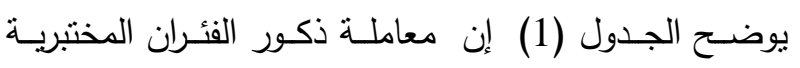

بالبروفين أدت الى ارتفاع معنوي (1)

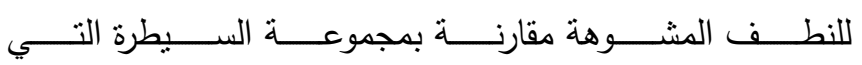

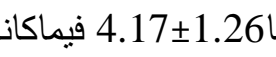
قيمته

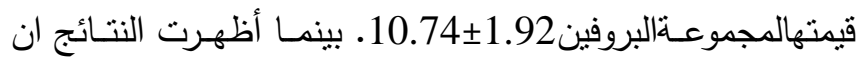
المعاملة بفيتامين C والبروفين وجود انخفاض في النسبة المئوية للنطف المشـوهة التي قيمتها

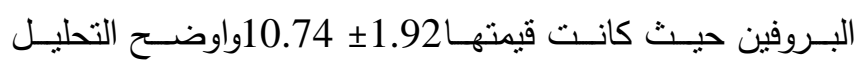

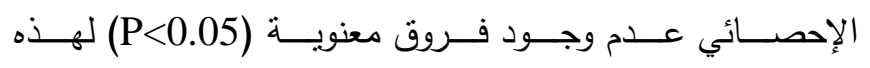

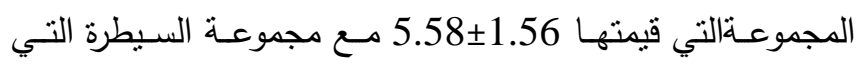

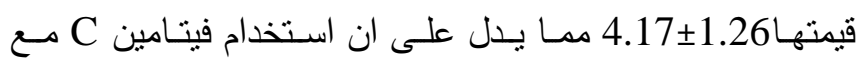

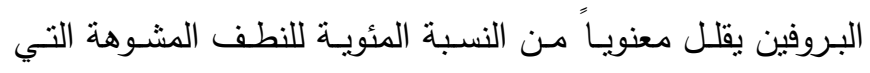

$$
\text { بسبيها البروفين. }
$$

يوضح الجدول(2) انخفاضًآ معنوياً (P<0.05 ) في معدل

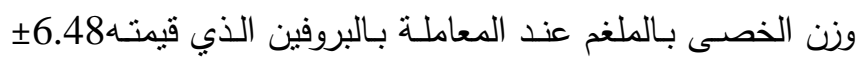

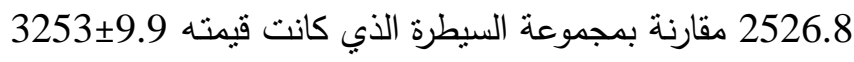
في حين لوحظ من النتائج ان معدل وزن الخصى كان مرتفعا

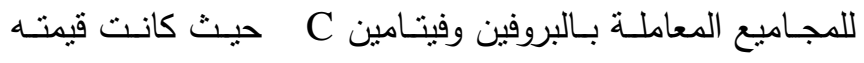

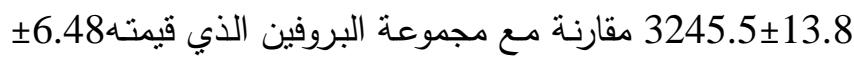

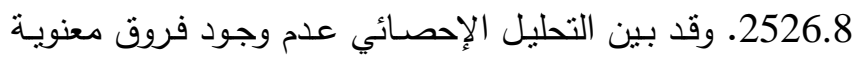

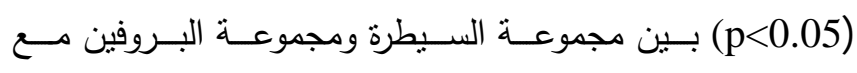
فيتامين C الذي كانت قيمته C

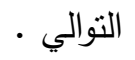

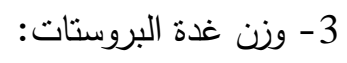

حضـر المحلـول بإذابـة (1غم) مـن صـبغة الايوسـين الصفراء (Eosin Yellowish) في (100مل) من الماء المقطر (Wyrobek \& Bruce, 1975). 3 - محلول البروفين حضـر محسول البروفين بتركيز (200ملغم/كلغم)مـن وزن الجسم بأذابة (20 ملغم) في( 10 مل) ماء مقطر .

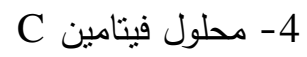
حضر محسول فيتامين C بتركيز ( 200ملغم/كلغم)مسن وزن الجسم بأذابة ( 20 ملغم) في (10 مل) ماء مقطر .

\section{فحص تثنوهات رؤوس النطف: Sperm Head}

Abnormality Assay

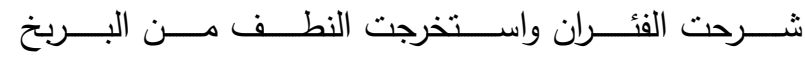

(Wyrobek \& Bruce, وباستخدام طريقة (Epididymis) (1975 وبحسب الخطوات الآتية:

1 - قطع البربخ ووضع في طبق بتري حاوي على (5 مل التهات : من المحلول الفسيولوجي وباستخدام شفرة حادة وملقط لئري

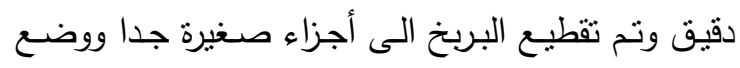
المحلول الحاوي على تلك الأجزاء في أنبوبـة اختبار

\section{نظيفة.}

2 - حضرت شرائح زجاجية نظيفة وفرشت قطرة من المحلول

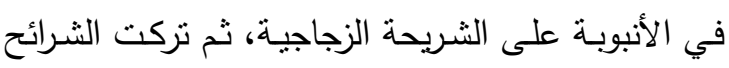
على صفيحة ساخنة (50م) لتجف. 3 - صبغت الثرائح الزجاجية الجافة بصبغة الايوسين (1)

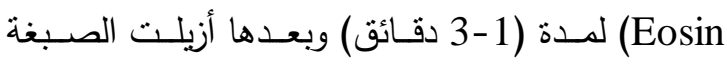

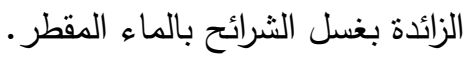

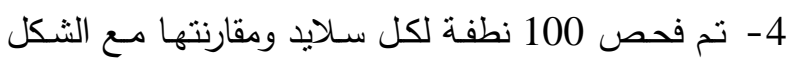

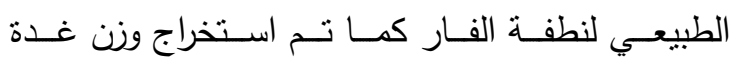
البروستات ووزن الخصى (Testis) . حساب اوزان الخصى وغدة البروستات :

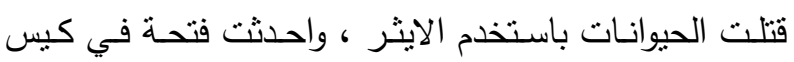
الصفن وادخل خلالها المقص ، واستمر القطع عبر القناة الاربية 
مجموعةالبروفين وفيتامين Cيث كانت قيمته 9.0 حقب 900 عند

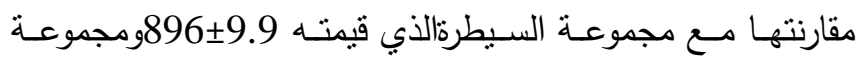
البروفين الذي قيمته $890 \pm 9.3$.

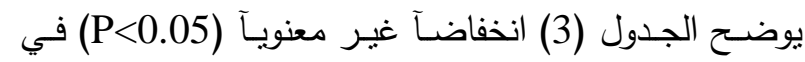

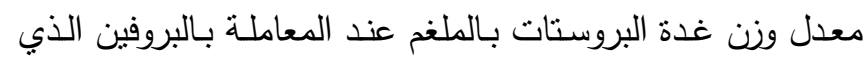

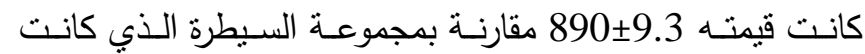
قيمته 896.9.9.وكذللك لم تكن الفروق معنوية (P>0.05) بين

جدول رقم (1) : يوضح تأثير البروفين وفيتامين C في تشوهات نطف ذكور الفئران المختبرية

\begin{tabular}{|c|c|c|}
\hline الثنبة المئوية لتَتُوهات رؤوس الثطف & عدد الفئران & المعاملات \\
\hline a $4.17 \pm 1.26$ & 12 & مجموعة البنبطرة \\
\hline bl0.74 \pm 1.92 & 12 & مجموعة البروفين \\
\hline a c $5.58 \pm 1.56$ & 12 & مجموعة البروفين +هيثامين C \\
\hline
\end{tabular}

تشير الحروف المتشابهة بين المعاملات الى عدم وجود فروق معنوية بينما تثير الحروف المختلفة الى وجود فروق معنوية بين المعاملات

جدول رقم (2):يوضح تأثثر البروفين وفيتامين C في وزن خصى ذكور الفئران

\begin{tabular}{|c|c|c|}
\hline 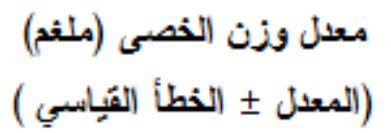 & عدد الفئران & المعاملات \\
\hline a $3253.4 \pm 9.9$ & 12 & مجموعة البسبطرة \\
\hline b $2526.8 \pm 6.48$ & 12 & مجموعة البروفين \\
\hline a c $3245.5 \pm 13.8$ & 12 & مجموعة البروفين +ويتامين C \\
\hline
\end{tabular}

تشير الحروف المتشابهة بين المعاملات الى عدم وجود فروق معنوية بينما تثير الحروف المختلفة الى وجود فروق معنوية بين المعاملات جدول رقم (3): يوضح تأثيرالبروفين وفيتامين C في وزن غدة بروستات ذكور الفئران

\begin{tabular}{|c|c|c|}
\hline معل وزن غدة البروستَات (ملثم) & عدد الفئر اث & المعاملات \\
\hline a $896 \pm 9.9$ & 12 & مجمو.عة اللسبطرة \\
\hline a $890 \pm 9.3$ & 12 & مجموعة البروفين \\
\hline a $\quad 900 \pm 9.0$ & 12 & مجموعة البروفين +فينامين C \\
\hline
\end{tabular}


Von Eular السايكلواوكسيجينز -1 و2 ، اذ وجد فون يولر

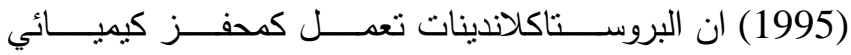
Chemical stimulator بالغدد الجنسية اللاحقة لافراغ محتوياتها من الافرازات المنويـة .

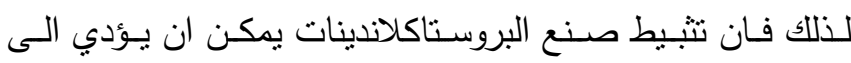
ارتخاء العضلات الملسـاء المحيطة بهذه الغدد وبالتالي عدم قدرة غدة البروستات من افراغ محتواها من الافرازات وبالتالي حصول Flint et. al. الزيادة في اوزانها ـ ومن ناحية اخرى فقد وجد (1995) ان البروسـتاكلاندين F2a يعهـل علـى تقليـل التجهيـز الدموي للخصى والغدد اللاحقة بها في ذكور الجرذان • وهذا ربما قد يفسر الزيادة الوزنية الناتجة عند المعاملة بفيتامين Cمن خلال

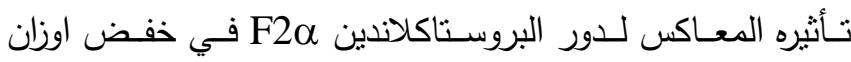

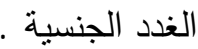

وان عـدم حدوث تغييـرات معنويـة في اوزان الخصسى عندـ

المعاملة بالبروفين قد يعود الى كون الجرعة غير كافية لاحداث

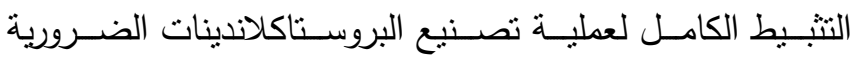
لوظائف الخصى والاعضاء الجنسية اللاحقة بها . وقد وجد Tokugawa et. al. (1998) بان البروستاكلاندينات تتركـز بشـكل كبيـر فـي السـائل المنـوي والخصـى والبروسـتات ومكونات سائل البربخ ـ لذلك فقد يكون الاندوميثاسين من خلال تتبيطه لتصنيع البروستاكلاندينات قد احدث تأثنيرا معاكسا وبالتالي

$$
\text { ادى الى زيادة في وزن غدة البروستات . ل }
$$

Bender, M. A.; Evans and Bacholz. (1988). Current status of cytogenetic proceaures to detect and quantify previous to radiation, mutat. Res., 196: 103-159.

Cole, A. S.; Eastoe, J. E.; Mcgivan, J.; Hayes, M. L. \& Smillie, A. C. (1988) Biochemistry and Oral Biology, $2^{\text {nd }}$ edition, London, pp. 156-169.

Flint, A.P.F., Frosling, M.L., Mitchell, M.D. and Turnbull, A.C (1995).Temporal relationship between changes in oxytocin and prostaglandin $\mathrm{F}$ levels in response to vaginal distension in the
المناقشة:

لقد وجد من نتائج البحث ان المعاملة بالبروفين اثرت بشكل سلبي على النطف في الفئران البالغة حيث لوحظ مـن نتائج البحث أن المعاملة بالبروفين بتركيز 200ملغم/كغم من وزن الجسم

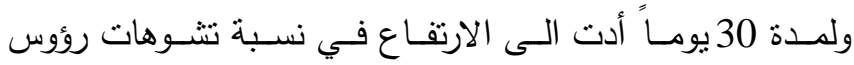
النطف مقارنـة مـع مجموعـة السيطرة وعند استخدام فيتامين بتركيز 200ملغم/كغم مـع البروفين بنفس التركيز أدت الى تحسين

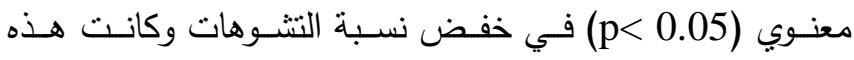
النتيجة مشابهة لما وجده Soares وجماعته (1979) م مايضا مشابهةتمع ما وجده Bruce وwyrobeck (1980) اللذان أشـارا الى إن استخدام فتامينC كمواد مضادة للأكسدة تعمل على تقليل تشوهات رؤوس النطف ـ وايضـآ مشابها مـع ما وجده Yamaski و Ames (1977) حيث وجدا من نتائج البحث ان استخدام فيتامين C ادى الى خفض النسبة المئوية للنطف المشوهة مقارنـة مع المجموعة المعاملة بالبروفين فقط ولم تكن الفروق معنويـة بين مجموعة السبطرة والمجموعة المعاملـة بفيتامين C مـع البروفين. في حين كانت الفروق معنويـة بين مجموعـة السيطرة ومجموعـة البروفين في النسبة المئوية للنطف المشوهة.وهذه النتيجة مشابهة لما وجده Topham (1980) الذي أشنار الى إن لبعض المواد

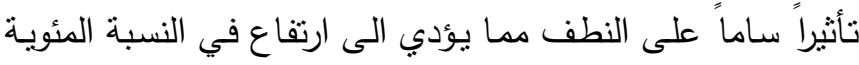
للنطف المشوهة والتي أشار الى النتيجة نفسها Bender et. (al., 1988. إما من ناحية معدل وزن الخصى وغدة البروستات

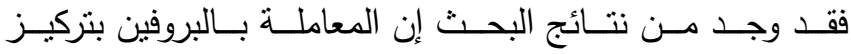

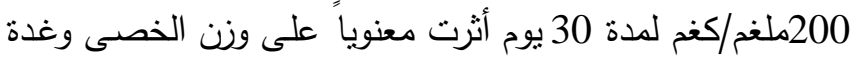
البروستات حيث ان معدل وزن الخصى قد انخفض عند الند المعاملة بالبروفين مقارنة بمجموعة السيطرة وقد ارتفع المعدل عند المعاملـة بالبروفين مـع فيتامين C بنفس التركيز مقارنـة بمجموعة السيطرة ومجموعـة البروفين وكذللك لـوزن غدة البروستات ولكن لـم تكن الفروق معنويـة في وزن غدة البروسـتات بين مجموعـة السيطرة ومجموعة البروفين ومجموعة البروفين مـع فيتامين C. ان الزيادة الحاصلة في اوزان الغدد الجنسية ربما تعود الى دور فيتامين Cفي تثيط صنع البروستاكلاندينات وذللك من خلال نتبيط انزيمي 
Topham, J. C. (1980). Induced sperm. Lead abnormalmalit in mice specifically identify mammalian mutagen rather than carcino-gens, Mutat. Res., 74: 379-387.

Verbeek, P. K. (1990). Pharmacokincdrug interaction with non steroida lantiin flammatorydrugs.

Von Euler, U.S.(1935). Adepressor substance in the vesicular gland. J.physiol., 84: 21. (Cited by Cenedella, R.J. (1995). Prostaglandins and male reproductive physiology. Adv. Sex. Horm. Kes., 1: 325-358.

West, D. W.; Slattery, M. L.; Robison, L. M. French, T. K. and Manony, A. W. (1994). Cancer causes coontrol2: 85-94 (cited by Louis et. al., 1996).

Wiley, (1989). Pharmaceutical chemicals in perspective, Reuben and witt koff, New York.

Wollff, S. (1981). Thesister chromatid exchange test 238-242.

Wyrobek, A. and Bruce, W. (1980). The induction of sperm shape abnormalities in mice and humans. Hollander (Eds.). chemical mutagens, Vol.6, plenuem NEWYORK.

Yamaski, E. and Ames, B. (1977). Concentration of mutagens from utine by adsorpation with the nonploar resin Xad-2, Proc. Natl. Acad. Sci., 74; 3555-3559. pregnant rat and puberal ewe. J. Reprod. Fert., 43: 551-554

Lee, C.Y.; Lee, K.W.; Lee, H.J. \& Kang, S.K. (2000) Explaining just how vitamin $\mathrm{C}$ works against cancer. J. Nutr, $359: 1-2$.

Moller, P. \& Loft, S. (2002) Oxidative DNA damage in human white blood cells in dietary antioxidant intervention studies. Am. J. Clin. Nutr. 76: 303310.

Ray, W. A.; Stein, C. M.; Hall, K.; Daugherty, J. R. and Griffin, M. R. (2000). Non-steroidal antiiflammatory drugs and risk of serious coronary heart disease an observational cohort study. Lancet. 359: 118-23.

Smirnoff, N. (2001) L-ascorbic acid biosynthesis. Vitamins and Hormones, 61 :241-265.

Soares, E., Shelidan, Maseman, J. and Segall, M. (1979). Increased frequencies of aberrant sperm as indication of mutagenic damage in mice. Mutant. Res., 64: 27-35.

Tokugawa, Y., Kunishige, I., Kubota, Y., Shimoya, K., Nobunaga, T., Kimura, T., Saji, F., Murata, Y., Eguchi, N., Oda, H., Urade, Y. and Hayaishi, O. (1998). Lipocalin-type prostaglandin D synthase in human male reproductive organs and seminal plasma. Biol. Reprod., 58: 600-607. 


\title{
The Effect of Profen and Vitamin C on rate of Sperm abnormalties and Weight of Testes and Prostate Gland of Male White Mice
}

\author{
Aseel Raheem Mardan \\ Department of Biology - College of Education - Al-Qadisiya University
}

\begin{abstract}
:
The present research was conducted on 36 white mice of similar weights by using one of the nonsteroid anti-inflammation drugs, namely profen. Vitamin $\mathrm{C}$ was used to assess the sperm abnormality; the testes mean weight, and prostate gland weight. The mice were divided into three equal groups. The mice of the first group were injected with profen $(200 \mathrm{mg}$. $/ \mathrm{kg}$. for each), the second was injected with profen and vitamin C (200mg. $/ \mathrm{kg}$. for each), and the third group was the control one. The mice of the first two groups were injected, in the peritoneum membrane once a day for a month.

The treatment with profen resulted into an increase in the percentage of the abnormal sperms compared to the control group $(10.74 \pm 1.92$ and $4.17 \pm 1.26$ respectively). The results have shown that the treatment with vitamin $\mathrm{C}$ and profen led to a decrease in the percentage of the abnormal sperms compared to the profen group $(10.74 \pm 1.92)$. The statistical analysis has shown considerable differences $(\mathrm{P}<0.05)$ for this group compared to the control one; this means that the use of vitamin $\mathrm{C}$ with profen decreases the percentage of abnormality effected by profen. Also, there happened a considerable decrease $(\mathrm{P}<0.05)$ in the testes weight treated with profen $(2526.8 \pm 6.48 \mathrm{mg}$.) compared to the control group (3203 $\pm 9.9 \mathrm{mg}$. $)$. However, the testes weight was high in the group treated with profen and vitamin C (3245.5 $\pm 13.8 \mathrm{mg}$.) compared to the profen group. In addition, there were no considerable statistical differences between the control group and the profen and vitamin $\mathrm{C}$ group.

As for the prostate gland, there was a considerable decrease $(\mathrm{P}<0.05)$ in the weight when treated with profen $(890 \pm 9.3 \mathrm{mg}$.) compared to the control group $(896 \pm 9.9 \mathrm{mg}$.). Furthermore, there were no statistically considerable differences $(\mathrm{P}<0.05)$ between the profen and vitamin $\mathrm{C}$ group $(900 \pm 9.0 \mathrm{mg}$.) compared to the control and profen groups.
\end{abstract}

